\title{
Impact of Cover Crops on Soil, Weeds and Citrus Trees Properties In Brazil
}

\author{
R.A. Abdel-Aziz*, Ademir Calegari*** and Paulo Vicente \\ Contador Zaccheo ${ }^{* * *}$ \\ ${ }^{*}$ Citrus Res. Dept., Horticulture Research Institute, ARC, \\ Cairo, Egypt ${ }^{* *}$ Soil Area, Instituto Agronomico do Parana' \\ (IAPAR), Londrina, Parana' State and ${ }^{* * *}$ Programa de Pós- \\ graduação em Agronomia, Universidade Estadual de Londrina, \\ Brazil.
}

\begin{abstract}
HE PRESENT investigation was carried out in the summer/ autumn season of 2010-2011/ 2011-2012 in citrus grove of the Scholl Farm of Universidade Estadual de Londrina - Paraná -Brasil. Eighteen 15-year-old Montenegrina mandarin (Citrus reticulata) trees grafted on Rangpur lime rootstock planted at $7 \times 4 \mathrm{~m}$ apart were selected to study the impact of some cover crop species on various soil and citrus trees properties. Six treatments; cultivating Stylosanthes guianensis var. vulgaris, Clitoria ternatea, Crotalaria juncea, Eleusine coracana, Mix of (Stylosanthes guianensis var. vulgaris, Clitoria ternatea and Eleusine coracana) and the fallow as control. Soil moisture and temperature; mandarin tree canopy and yield, cover crop density, biomass and root system; weed identification and density were measured. Both Clitoria ternatea and the Mix of (Stylosanthes guianensis var. vulgaris, Clitoria ternatea, and Eleusine coracana) gave the best results.
\end{abstract}

Keywords: Citrus, Weeds, Cover crop, Yield.

In the last few decades, citrus fruit world production has experienced continuous growth. The rise in citrus production is mainly due to the increase in cultivation areas and the change in consumer preferences towards more health and convenience food consumption and the rising incomes (UNCTAD according to FAO data, 2004). It is an evidence that citrus is important from the socioeconomic and technical aspects allover the world.

Soil management practices in citrus orchards under the conditions of tropical and subtropical climates are very important. The common citrus orchards ground practice in Sao Paulo state, Brazil is the combination of mowing and tillage during rainy and dry seasons, respectively (Negri, 1988). However, the intensive use of disk tillage, creates compaction problems, reduction in the water infiltration rate, increase erosion risks and damages to the trees root system (Neves et al., 1998). Moreover, Traffic in the inter-row is other reason contributing to the increase in soil density and thus cause reduction in root growth, aeration, water potential, and penetration resistance. Citrus root systems have shown great differences in shape, quantity, root depth and susceptibility to 
soil compaction (Neves et al., 2004 and Kemper, 1981). The root system is restricted in compacted soils (Anghinoni and Meurer, 1999) which have a negative impact on citrus trees performance.

According to the previous studies, some cover crops have a taproot that can create channels into the subsoil. Others have a massive, fine root system that intermeshes with soil particles, stabilizing aggregation and creating many small channels. Deep-rooted cover crops may help alleviate effects of soil compaction (Williams and Weil, 2004). On the other hand, there was no convincing evidence that above-ground biomass of some cover crops contributed directly to the reduction of machine-induced compaction effects (Ess et al., 1998).

The present investigation is aiming at evaluating the influences of some cover crops on citrus tree growth, yield, their ability to compete with weeds, to evaluate their root distribution and the influence on various soil parameters.

\section{Material and Methods}

\section{Characterization of the experiment site}

The study was carried out in the summer/autumn season of 2010 \& 2012 in citrus grove of the Scholl Farm of Universidade Estadual de Londrina - Paraná Brasil. $550 \mathrm{~m}$ above the sea level, latitude $23^{\circ} 34^{\prime} \mathrm{S}$ and longitude $51^{\circ} 21^{\prime} \mathrm{W}$. The soil is characterized as Oxisol Distroferrico typical red clay (EMBRAPA, 1999), rainfall annual average of $1610 \mathrm{~mm}$ and annual average temperature of $21.2{ }^{\circ} \mathrm{C}$.

Eighteen 15-year-old Montenegrina mandarin (Citrus reticulata) trees grafted on Rangpur lime rootstock planted at $7 \mathrm{~m} \times 4 \mathrm{~m}$ apart were selected for this investigation. The trees are of almost uniform vigor and received the customary horticultural practices for pruning, organic fertilization, etc. The trees received the recommended fertilization program according to the GROUP of PAULISTA fertilization and liming for citrus (1994).

\section{Experimental design and statistical analysis}

The CRBD design of six treatments with three replicates was followed throughout the whole work. Each replicate was represented by one tree. The treatments were; cultivating Stylosanthes guianensis var. vulgaris, Clitoria ternatea, Crotalaria juncea, Eleusine coracana, Mix of (Stylosanthes guianensis var. vulgaris, Clitoria ternatea, and Eleusine coracana) ] and the fallow as control. The obtained data were statistically analyzed using the Statistical Analysis System (SASM-Agri). The effects were tested using the general Linear Model. Multiple comparisons of means were performed according to Duncan test (Snedecor \& Cochran, 1972).

\section{Establishment of the tested cover crop species}

The seed bed was prepared between the trees rows. The cover crops were cultivated in a quadrate $4 \times 4 \mathrm{~m}$ of each side of the mandarin tree. The total Egypt. J. Hort. Vol. 40, No.1 (2013) 
surface area needed for cover crop was $345.6 \mathrm{~m}^{2}$. The seeds were sown in November with the recommended rates. Cover crops were incorporated in the flowering bloom.

\section{Cover crop parameters}

Cover crop seeds germination \%: Measuring seed germination was done by counting the emergence of 100 seeds in seed bed and the percentage was calculated as follows: number of germinated seeds/ 100 .

Cover crop density: A $50 \mathrm{~cm}$ x $50 \mathrm{~cm}$ quadrate was used and the cover crops density was visually evaluated.

Cover crops height: The height of fifty plants of the cover crops was measured and the average was calculated in $\mathrm{cm}$.

Cover crops dry weight biomass: Dry weight biomass was measured at the end of the each growing cycle in three representative squares of $50 \times 50 \mathrm{~cm}$ quadrate in each treatment.

Cover crops root system: Cover crops root weight was determined using the root and soil cover analysis system SIARCS 3.0 (Crestana et al., 1994).

\section{Weed parameters:}

Emerged weed seedlings were periodically identified according to Harri (2006) and Hanf (1990) then counted and removed. Actual weed infestation was measured by counts in two fixed $50 \times 50 \mathrm{~cm}$ quadrate per plot carrying out at the end of each month and the average was calculated. Weed density and fresh weight biomass was measured.

\section{Soil parameters}

Soil samples: Soil samples were collected at the end of the experimental season at $0-20,20-40,40-60 \mathrm{~cm}$ depths with the aid of $3.5 \mathrm{~cm}$ diameter soil auger. Five auger points were taken along the diagonals of each plot. Samples from the same plot and the same soil depth were bulked, homogenized and composite samples were taken to the laboratory for analyses. The following soil parameters were measured:

\section{Soil moisture contents}

Soil moisture percentage was determined using 5TE sensor, Decagon Devices Court Pullman WA99163. The level of soil moisture was considered high $(>8$ $\%)$, intermediate $(4.2-8 \%)$ and low $(<4.2 \%)$ according to the American Soil Taxonomy (1975).

\section{Citrus tree measurements}

Tree canopy volume: At the beginning of the experiment the canopy volume $\left(\mathrm{m}^{3}\right)$ [calculated according to the equation: Canopy volume $\left(\mathrm{m}^{3}\right)=0.5236 \mathrm{x}$ height $\mathrm{x}$ diameter square as stated by Turell (1965). The same measurements 
were done once more at the end of the experiment, one year later. The yearly increments in tree canopy volume were calculated.

Yield/hectare: At the end of the experimental seasons, the number of fruit per tree was counted then a sample of 10 fruits were weighted and the average fruit weight was taken. The yield per hectare/ton was calculated theoretically as follows $=$ [average fruit weight $(\mathrm{g}) \mathrm{x}$ number of fruit/tree $\mathrm{x}$ number of trees $/$ hectare $] / 1000$ (hectar $=2.38$ feddens).

\section{Cover crop parameters}

\section{Results and Discussion}

Cover crop seeds germination $\%$

Data presented in Fig. 1 refer to the cover crop seed germination percentage in both experimental seasons. The data showed significant differences between the tested cover crops. The higher germination percentage resulted with Crotalaria juncea while Clitoria ternatea gave the lowest value. This could be due to the differences in the seed viability of the tested species. In this respect, the timing, the climatic conditions and ensuring good seed to soil contact are important for germination success (Morgan, 1997). However, it is difficult to choose the best conditions for all species in one single seeding technique because native seeds vary so widely in their germination requirements (Munshower, 1994). The obtained results gave an evident that the best seeding time for Crotalaria juncea is November.

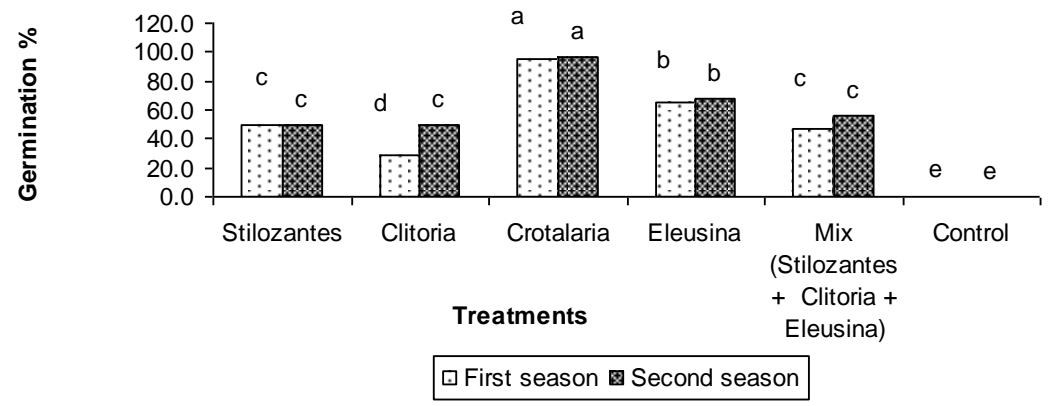

Fig. 1. Cover crop seeds germination percentage in Montenegrina mandarin orchard submitted to treatments of cover crops.

Means followed by the same letter are not significantly different at $\mathrm{P}=0.05$ (Duncan test).

Cover crop density

It was clear that both Clitoria ternatea and the Mix of (Stylosanthes guianensis var. vulgaris, Clitoria ternatea and Eleusine coracana) gave the optimal results with $100 \%$ soil cover while Eleusine coracana and Crotalaria juncea occupied the second and third positions with $98 \%$ and $80 \%$, respectively. The least cover crop density resulted from the use of Stylosanthes guianensis var. vulgaris with $30 \%$. These results can be referring to the excellent seed viability

Egypt. J. Hort. Vol. 40, No.1 (2013) 
or to the germination rate as shown in Fig 2 and/ or the rapid growth of Clitoria ternatea (Conway et al., 2001) and Crotalaria juncea and the Mix of (Stylosanthes guianensis var. vulgaris, Clitoria ternatea, and Eleusine coracana) while Stylosanthes guianensis var. vulgaris was grown leisurely. However, the differences between all the tested cover crops were significant.

\section{Cover crops height}

The obtained results in Fig. 2 showed that Crotalaria juncea followed by Eleusine coracana and the Mix of (Stylosanthes guianensis var. vulgaris, Clitoria ternatea, and Eleusine coracana) treatments gave the highest values while Stylosanthes guianensis var. vulgaris gave the lower value. The differences between cover crops were statistically significant. These results are in agreement with those of Yost and Evans, (1988). In general, as much as the cover crop has a rapid growth and cover large area of the cultivated soil in short time as much as it is superior (USDA, 1998), such trend was not noticed in the case of Stylosanthes guianensis var. vulgaris where the growth was slow that reached $(25 \mathrm{~cm})$ compared to Crotalaria juncea $(198.7 \mathrm{~cm})$ and consequently the final height was less than the other tested spices. Moreover, it produce less amount of biomass compared to the other tested cover crop species.

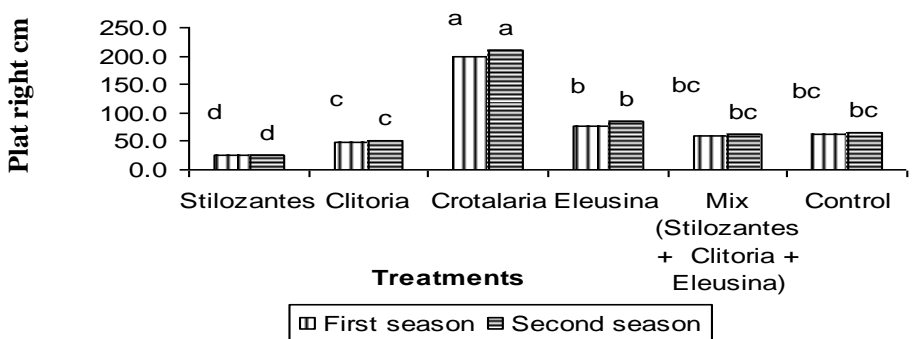

Fig. 2. Cover crop height $(\mathrm{cm})$ in Montenegrina mandarin orchard submitted to treatments of cover crops

Means followed by the same letter are not significantly different at $\mathrm{P}=0.05$ (Duncan test).

Cover crops dry weight biomass

Data in Fig. 3 showed significant differences between the tested cover crops in dry weight biomass contents. The highest value of dry matter biomass resulted from the use of Eleusine coracana followed by the Mix of (Stylosanthes guianensis var. vulgaris, Clitoria ternatea, and Eleusine coracana). However, Stylosanthes guianensis var. vulgaris gave the lowest results. On the other hand, the differences between Clitoria ternatea and Crotalaria juncea and the Mix of (Stylosanthes guianensis var. vulgaris, Clitoria ternatea, and Eleusine coracana) were not significant. The obtained results are in harmony with the results of cover crop height and it can be due to the growth rate of the tested cover crops. We can notice that the growth rate of Stylosanthes guianensis var. vulgaris resulted in 2.5 ton/ha while Eleusine coracana gave 11.5 ton/ha. The results also showed that the legume cover crops resulted in lower amount of dry biomass 
compared to the grass. However, these results are confirmed by Yost and Evans, (1988), Duke, (1979) and USDA, (1998).

Thus, the increase in cover crop biomass adds to the soil organic matter and enhances the soil physical and chemical properties (USDA, 1998).

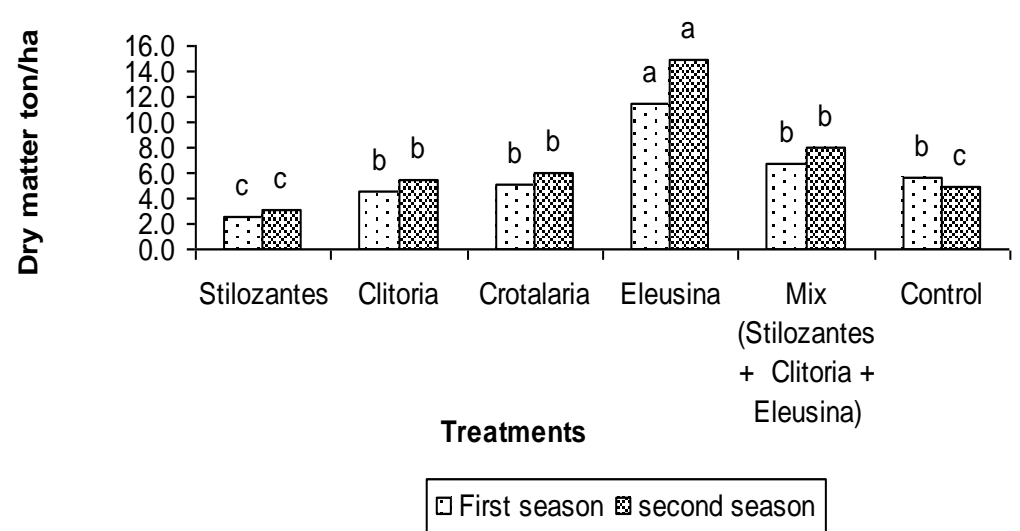

Fig. 3. Cover crop dry matter (ton/ha) in Montenegrina mandarin orchard submitted to treatments of cover crops

Means followed by the same letter are not significantly different at $\mathrm{P}=0.05$ (Duncan test).

Cover crops root system

The results of cover crop roots weight Fig. 4 showed the average results of both experimental seasons. The highest values were noticed at $(0-20 \mathrm{~cm})$ of soil surface. Whereas the lowest values were obtained with the depth of $40-60 \mathrm{~cm}$. The differences between cover crop root weights were not significant in the depth of $(0-20 \mathrm{~cm})$ while the results of the depths $(20-40$ and $40-60 \mathrm{~cm})$ gave significant differences. However, it was clear that Stylosanthes guianensis var. vulgaris has shallow roots while Clitoria ternatea followed by Eleusine coracana and the Mix of (Stylosanthes guianensis var. vulgaris, Clitoria ternatea, and Eleusine coracana) has deeper roots that helps in exploring large area of the soil searching for nutrients and water.

The fact that Stylosanthes guianensis var. vulgaris has shallow and limited root system have advantages because these roots will not compete with the mandarin tree roots for the nutrients and water. On the other hand, it is also disadvantages because the growth of Stylosanthes guianensis var. vulgaris becomes very slow and loose the competitiveness with weeds and it takes time to cover large area of the soil in short time.

Generally, cover crop root system helps stabilize the soil by infiltrating the profile and holding it in place and thus reduce soil erosion (Sainju and Singh 1997).

Egypt. J. Hort. Vol. 40, No.1 (2013) 
Furthermore, the Mix of (Stylosanthes guianensis var. vulgaris, Clitoria ternatea, and Eleusine coracana) that includes grasses and legumes with shallow and deeper root system can therefore be more effectively to prevent soil erosion and reduce soil $\mathrm{N}$ concentration. Competition for soil $\mathrm{N}$ in mixed stands can also result in increasing biological $\mathrm{N}$ fixation by the legume (Ranells and Wagger, 1997).

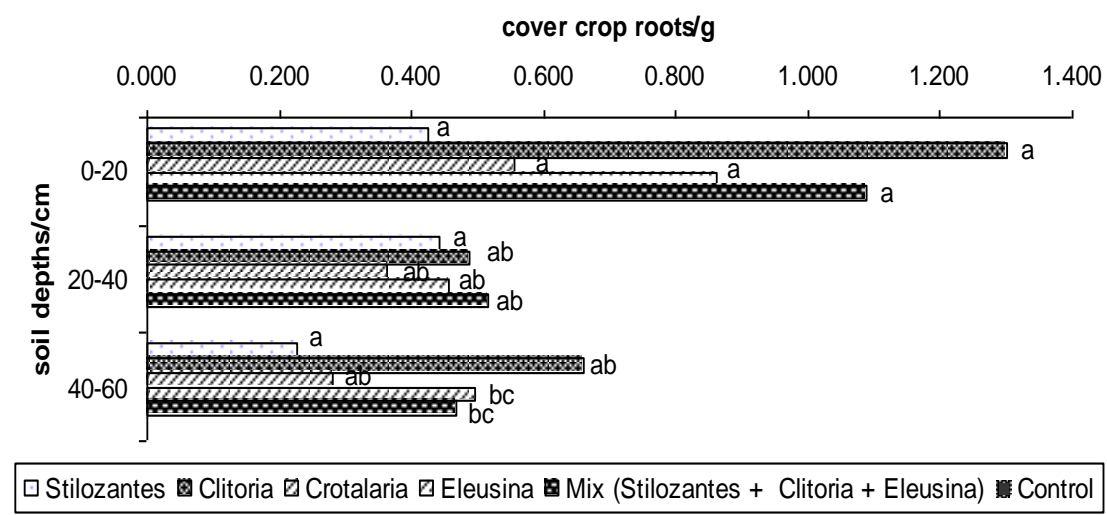

Fig. 4. Cover crop root system (g) in Montenegrina mandarin orchard submitted to treatments of cover crops.

\section{Weed parameters}

Weed identification

Table 1 represents the most common weed species that has been grown during the experimental season. Generally, most of those species are commonly grown under this area and prevailing climatic conditions.

TABLE 1. The common weed varieties in the experimental location.

\begin{tabular}{|l|l|}
\hline \multicolumn{1}{|c|}{ Variety scientific name } & \multicolumn{1}{c|}{ Variety scientific name } \\
\hline - Amaranthus deflexus & - Sida rhomboidea \\
- Amaranthus hypochondriacus var. Patulus & - Richardia brasiliensis gomes \\
- Bidens pilosa & - Soliva pterosperma (juss) less \\
- Cenchrus echinatus & - Stellaria media L. vill \\
- Chamaesyce hyssopifolia & - Oxalis corniculata \\
- Commelina benghalensis & - Oxalis latifolia kunth \\
\hline
\end{tabular}

Weed density (number $/ 50 \mathrm{~cm}^{2}$ ) and fresh weight biomass

The least weed density was found with the Eleusine coracana while both Stylosanthes guianensis var. vulgaris and the control followed by the Mix of (Stylosanthes guianensis var. vulgaris, Clitoria ternatea, and Eleusine coracana) gave the highest values (Table 2). The differences between the tested cover crops were significant in both seasons. The lowest weed density results have been 
connected with Eleusine coracana, Crotalaria juncea and Clitoria ternatea, respectively. Whereas the highest weed density was obtained from the use of Stylosanthes guianensis var. vulgaris and the control treatment.

TABLE 2. Weed density (number $/ 50 \mathrm{~cm}^{2}$ ) and fresh weight biomass of Montenegrina mandarin orchard submitted to treatments of cover crops

\begin{tabular}{|c|c|c|c|c|}
\hline \multirow[b]{2}{*}{ Treatments } & \multicolumn{4}{|c|}{ Weed parameters } \\
\hline & \multicolumn{2}{|c|}{$\begin{array}{c}\text { Weed density } \\
\left(\text { Number } / 50 \mathrm{~cm}^{2}\right)\end{array}$} & \multicolumn{2}{|c|}{$\begin{array}{l}\text { Weed fresh biomass } \\
\text { (g) }\end{array}$} \\
\hline Stilozantes & $9.83 \mathrm{a}$ & $9.5 \mathrm{a}$ & $98.73 a b$ & $90.22 \mathrm{~b}$ \\
\hline Clitoria & $6.83 \mathrm{ab}$ & $5.95 \mathrm{~b}$ & $45.45 \mathrm{ab}$ & $39.34 \mathrm{c}$ \\
\hline Crotalaria & $6.67 \mathrm{ab}$ & $5.00 \mathrm{~b}$ & $23.87 \mathrm{~b}$ & $30.33 \mathrm{c}$ \\
\hline Eleusina & $4.00 \mathrm{~b}$ & $3.50 \mathrm{c}$ & $31.93 \mathrm{~b}$ & $25.45 \mathrm{~d}$ \\
\hline $\begin{array}{l}\text { Mix (Stilozantes + } \\
\text { Clitoria + Eleusina) }\end{array}$ & $7.50 \mathrm{ab}$ & $6.50 \mathrm{ab}$ & $52.32 \mathrm{ab}$ & $44.23 \mathrm{bc}$ \\
\hline Control & $8.33 \mathrm{a}$ & $12.23 \mathrm{a}$ & $192.92 \mathrm{a}$ & $200.45 \mathrm{a}$ \\
\hline
\end{tabular}

Generally, all cover crop treatments resulted in a decrease in the number of weeds compared to the control treatment.

Table 2 also showed the results of weed fresh biomass. All tested cover crops resulted in lower weed fresh biomass than the control. The differences were statistically significant and the trend line shows an increase in the amount of weed biomass particularly in the control treatment. In this respect, the highest value of weed fresh biomass resulted from the control followed by Stylosanthes guianensis var. vulgaris. Both Clitoria ternatea and the Mix of (Stylosanthes guianensis var. vulgaris, Clitoria ternatea, and Eleusine coracana) treatments showed intermediate levels of competitiveness between the grown weeds and the cover crop species. However, the highest level of competitiveness was obtained with Crotalaria juncea and Eleusine coracana. These trends can be explained by taking into consideration that the growth of Stylosanthes guianensis var. vulgaris was slower than the growth of Clitoria ternatea and the Mix of (Stylosanthes guianensis var. vulgaris, Clitoria ternatea and Eleusine coracana) while the growth of Crotalaria juncea and Eleusine coracana was fast. This gave advantage to Crotalaria juncea and Eleusine coracana plants to prevent the light to reach weed plants. In addition to the competition with the weeds for water and nutrients while Stylosanthes guianensis var. vulgaris was not able to compete. However, it was clear that the cover crop species was better than the control.

Indeed, many cover crops can suppress the growth of weeds. Some produce thick canopies that prevent light from reaching the surface of the soil. This can weaken competing weed species and suppress weed seed germination. Cover crops have also been reported to exhibit allelopathic effects. "Allelopathy is the

Egypt. J. Hort. Vol. 40, No.1 (2013) 
beneficial or harmful influence of one plant on another plant by the secretion of a chemical or toxic substance" (Hanwen et al., 2007).

In general, planting mixtures of cover crops can take advantage of the allelopathic potential of the cover crops to suppress weeds. Allelopathic suppression of weeds has been shown to be a species specific phenomenon, therefore a broader spectrum of weed control may be possible by growing a mixture of cover crop species, each contributing allelopathic activity towards specific weed species (Creamer and Bennett, 1997).

From the two experimental seasons, we can conclude that weed suppression due to cover crops is likely to have a function of both numbers of cover crop plants and cover crop biomass (Carol and Martin, 2003).

\section{Soil parameters}

Soil moisture contents

Figure 5 showed the average of soil moisture content of both the experimental seasons. The results showed that the difference between soil moisture percentages due to the tested cover crop species were not significant in the first season while in the second one showed significant differences. This is true since the effect of cover crops needs more time to show the accumulation effect (USDA, 1998). However, the soil moisture level in March was low $(<4.2 \%)$ while it was intermediate $(4.2-8 \%)$ in May and high (> 8\%) in Jan. (American Soil Taxonomy, 1975). The obtained results could be due to the fact that in March the cover crop plants require higher amount of water for growth and physiological process whereas in Jan. their water requirements were less than the water requirements in May and March. In addition, this might be due to the properties of the experimental soil and the influence of the cover crops (USDA, 1998). These results are in line with the obtained results of cover crop biomass since the species that produce high amount of biomass such as Eleusine coracana, Clitoria ternatea and the Mix of (Stylosanthes guianensis var. vulgaris, Clitoria ternatea and Eleusine coracana) increase the value of soil moisture which is relatively related with the period of plant growth (James, 2009).

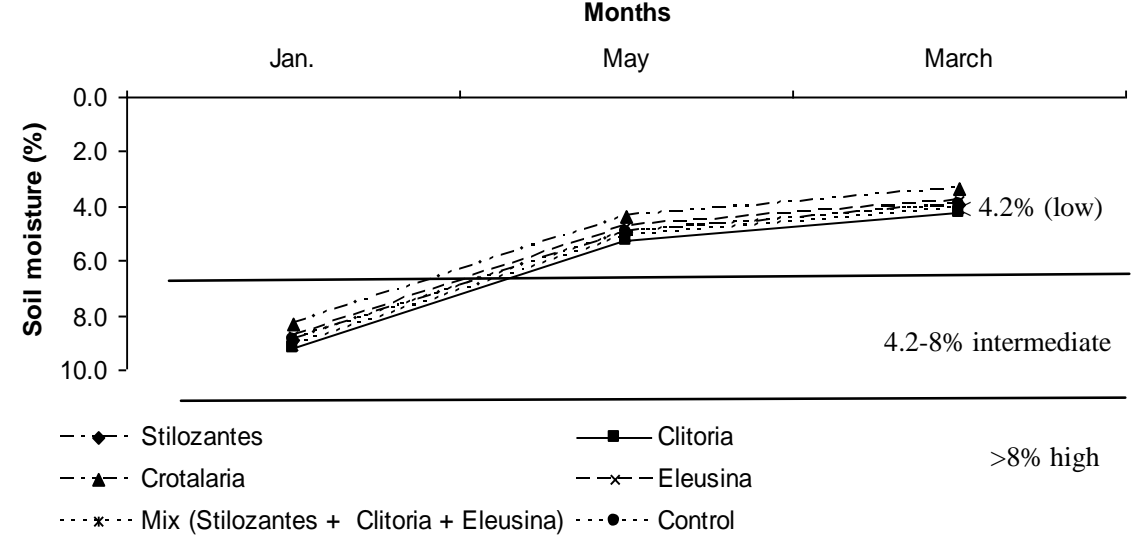

Fig. 5. Soil moisture percentage of Montenegrina mandarin orchard submitted to treatments of cover crops. 
Soil temperature at 0 and $5 \mathrm{~cm}$ from soil surface

The data in Fig. 6 showed that the average of soil temperature in both experimental seasons had no significant differences between all the tested cover crops in the two depths 0 and $5 \mathrm{~cm}$ from the soil surface. Overall, it is noticed that the soil temperature at the depth of $5 \mathrm{~cm}$ was lower than the temperature at $0 \mathrm{~cm}$. The differences in soil temperature that ranged from 0.93 to $2.57^{\circ} \mathrm{C}$ in the depths of 5 and $0 \mathrm{~cm}$ from soil surfaces, respectively.

In this respect, Dabney et at. (2001) declared that living cover crops can significantly alter soil temperatures, decreased the amplitude of day and night temperatures more than average temperatures resulting in less variability. Cover crop mulches protect the soil from cold nights and slow cooling. This could be useful in hot regions, but may slow growth in cooler regions. However, they found that winter cover crops moderate temperatures in the winter and the standing crops have higher soil temperatures than flat crops. These results were in agreement with our obtained results even though the results were not significant.

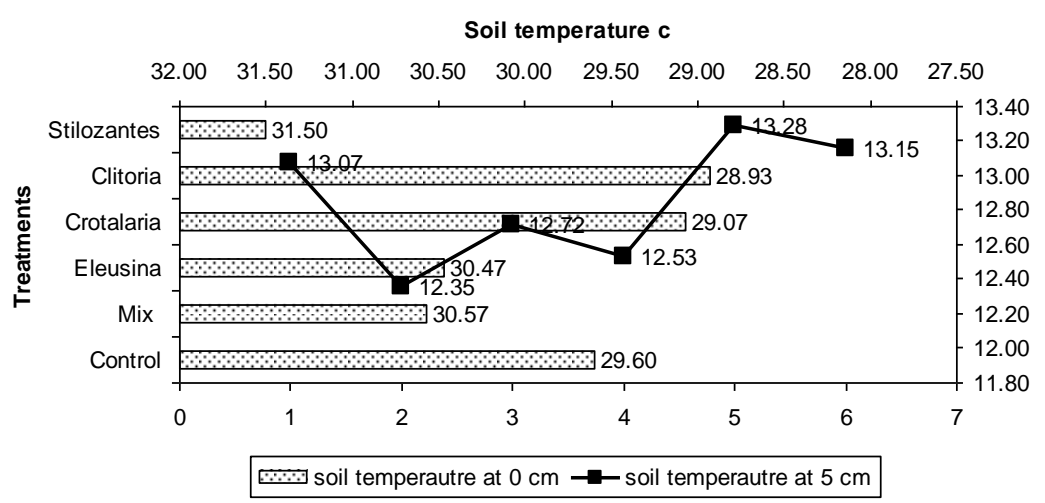

Fig. 6. Soil temperature ${ }^{\circ} \mathrm{C}$ of Montenegrina mandarin orchard submitted to treatments of cover crops.

These results also could be due to the differences in the biomass production of the tested species where as much as the amount of biomass as much as the soil is covered that prevent the sunrays to reach the soil surface. In addition, as a result for soil cover, the soil moisture enhance lowering the soil temperature.

\section{Citrus tree measurements}

Tree canopy volume

The effect of cover crop species on tree canopy volume was not significant in the first season while the results showed significant differences in the second season (Table 3). However, the highest value resulted from the cultivating of Clitoria ternatea, Crotalaria juncea and the Mix of (Stylosanthes guianensis var. vulgaris, Clitoria ternatea, and Eleusine coracana) followed by Eleusine coracana, Stylosanthes guianensis var. vulgaris and the control. These results could be due to the fact that legumes help to fix nitrogen into the soil and

Egypt. J. Hort. Vol. 40, No.1 (2013) 
therefore increase the vegetative tree growth (Abdel-Aziz et al., 2008). On the other hand, the significant results obtained in the second season were due to the accumulation effect of the cover crop species (USDA, 1998).

TABLE 3. Tree Canopy volume increments $(\mathrm{m})$ of Montenegrina mandarin orchard submitted to treatments of cover crops

\begin{tabular}{|l|c|c|}
\hline \multicolumn{1}{|c|}{ Treatments } & $\begin{array}{c}\text { Tree canopy } \\
\text { increments } \\
\text { First season } \\
(\mathbf{m})\end{array}$ & $\begin{array}{c}\text { Tree canopy } \\
\text { increments } \\
\text { Second season } \\
(\mathbf{m})\end{array}$ \\
\hline Stilozantes & $0.91 \mathrm{a}$ & $0.99 \mathrm{~b}$ \\
Clitoria & $1.39 \mathrm{a}$ & $1.42 \mathrm{a}$ \\
Crotalaria & $1.33 \mathrm{a}$ & $1.35 \mathrm{a}$ \\
Eleusina & $0.96 \mathrm{a}$ & $0.90 \mathrm{~b}$ \\
Mix (Stilozantes + Clitoria + Eleusina) & $1.10 \mathrm{a}$ & $1.20^{\mathrm{a}}$ \\
Control & $0.55 \mathrm{a}$ & $0.50 \mathrm{c}$ \\
\hline
\end{tabular}

Means followed by the same letter are not significantly different at $\mathrm{P}=0.05$ (Duncan test).

Number of fruit/tree, fruit weight/g and yield/hectare/ton

Data in Table 4 clarify that statistically there were significant differences between all the tested cover crops. However, Crotalaria and Clitoria ternatea followed by the Mix of (Stylosanthes guianensis var. vulgaris, Clitoria ternatea, and Eleusine coracana) gave the higher yield values with 19.4, 18.4 and 17.2 ton/ha in the second season, respectively. This can be a result of the improving in tree growth achieved by the existing of legumes which improve soil fertility and enhance tree roots efficiency to absorb water and nutrients, in addition to the increase in soil fertility (Abdel-Aziz et al., 2008). However, we declare that the effect of cover crop practices needs more than two seasons to fulfill clear and sustainable results.

TABLE 4. Number of fruit/tree, fruit weight/g and yield/ hectare/ ton of Montenegrina mandarin in an orchard submitted to treatments of cover crops

\begin{tabular}{|l|c|c|c|c|c|c|}
\hline \multirow{2}{*}{ Treatments } & \multicolumn{2}{|c|}{ No. of fruit/tree } & \multicolumn{2}{c|}{ Fruit weight/g } & \multicolumn{2}{c|}{ Yield/ha/ton } \\
\cline { 2 - 7 } & $\begin{array}{c}\text { First } \\
\text { season }\end{array}$ & $\begin{array}{c}\text { Second } \\
\text { season }\end{array}$ & $\begin{array}{c}\text { First } \\
\text { season }\end{array}$ & $\begin{array}{c}\text { Second } \\
\text { season }\end{array}$ & $\begin{array}{c}\text { First } \\
\text { season }\end{array}$ & $\begin{array}{c}\text { Second } \\
\text { season }\end{array}$ \\
\hline Stilozantes & $290 \mathrm{~b}$ & $305 \mathrm{~b}$ & $155 \mathrm{a}$ & $150 \mathrm{a}$ & $16.0 \mathrm{a}$ & $16.3 \mathrm{~b}$ \\
Clitoria & $310 \mathrm{a}$ & $340 \mathrm{a}$ & $160 \mathrm{a}$ & $152 \mathrm{a}$ & $17.7 \mathrm{a}$ & $18.4 \mathrm{a}$ \\
Crotalaria & $323 \mathrm{a}$ & $350 \mathrm{a}$ & $150 \mathrm{a}$ & $155 \mathrm{a}$ & $17.3 \mathrm{a}$ & $19.4 \mathrm{a}$ \\
Eleusina & $300 \mathrm{~b}$ & $295 \mathrm{~b}$ & $115 \mathrm{~b}$ & $120 \mathrm{~b}$ & $12.3 \mathrm{~b}$ & $12.6 \mathrm{c}$ \\
Mix (Stilozantes + & $310 \mathrm{a}$ & $345 \mathrm{a}$ & $155 \mathrm{a}$ & $140 \mathrm{a}$ & $17.2 \mathrm{a}$ & $17.2 \mathrm{a}$ \\
Clitoria + Eleusina) & $300 \mathrm{~b}$ & $290 \mathrm{~b}$ & $130 \mathrm{~b}$ & $112 \mathrm{c}$ & $13.9 \mathrm{~b}$ & $11.6 \mathrm{c}$ \\
Control &
\end{tabular}

Means followed by the same letter are not significantly different at $\mathrm{P}=0.05$ (Duncan test). 


\section{Conclusion}

The obtained results indicated that the use of a mix between legumes and grasses enhance soil physical and chemical properties.

Moreover, it is noticed that some of the tested cover crop species such as Stylosanthes guianensis var. vulgaris has slow growth and thus has less ability to compete with weeds and other types of cover crops when mixed. Both Clitoria ternatea and Eleusine coracana showed highly competitiveness to weeds and also produce sufficient amount of biomass that add more value to the soil and increase its fertility. In addition, the use of cover crop practices improve mandarin trees growth and increase the final yield.

Generally, we recommend repeating the same experiment for several years to achieve the cumulative effect of cover crops on both the soil and the mandarin trees.

\section{References}

Abdel-Aziz, R.A., Salem, S.E. and Al-Bitar, L. (2008) Effect of Inter-cropping Cover Crops on Citrus Orchards Growth and Fruiting under Toshka Conditions. J. Agric. and Veterinary Sci., Qassim University, 1 (2), 57-66.

American Soil Taxonomy (1975) Soil Taxonomy, A basic system of soil classification for making and interpreting soil surveys. Soil Conservation Survey, U.S. Dept. Agric., Hand book, 436.

Anghinoni, I. and Meurer, E.J. (1999) Eficiência de absorção de nutrientes pelas raízes. In: workshop sobre sistema radicular: Metologias e estudo de casos, 1., Aracaju. Anais. Aracaju: EMBRAPA : 57- 87.

Carol, A. M. and Martin, N. (2003) Can cover crop control weeds? Agriculture and environment news. A monthly report on pesticides and related issues. no 203. http://aenews.wsu.edu.

Conway, M.J., McCosker, K., Osten, V., Coaker, S. and Pengelly, B.C. (2001) Butterfly Pea - A Legume Success Story in Cropping Lands of Central Queensland. In: Rowe, B., Mendham, N. and Donaghy, D. (Ed.) Proceedings of the $10^{\text {th }}$ Australian Agronomy Conference, Hobart.

Creamer, N.G. and Bennett, M.A. (1997) Evaluation of cover crop mixtures for use in vegetable production systems. Hort Science, 32,866-870.

Crestana, S., Guimaraes, M. F., Jorge, L.A.C., Ralisch, R., Tozzi, C.L., Torreneto, A. and VAZ, C.M.P. (1994) Avaliação da distribuição de raízes no solo auxiliada por processamento de imagens digitais. Revista Brasileira de Ciência do Solo, 18 (3), 365371.

Dabney, S.M., Delgado, J.A. and Reeves, D.W. (2001) Using winter cover crops to improve soil and water quality. Community of Soil Science Plant Analysis, 32 (7\&8), 1221-1250.

Egypt. J. Hort. Vol. 40, No.1 (2013) 
Duke, J.A. (1979) Ecosystematic data on economic plants. Quart. J. Crude Drug Res. 17(3-4), 91-110.

Ess, D.R., Vaughan, D.H. and Perumpral, J.V. (1998) Crop residue and root effects on soil compaction. Transactions of the ASAE, 41(5), 1271-1275.

Grupo Paulista De Adubacao Calagem Para Citros (1994) Recomendações de adubação e calagem para citros no estado de São Paulo. 3. ed. Cordeirópolis, Edição especial.

Hanf, M. (1990) Le infestanti de Europa, le loro plantule, i loro semi. Ed. Basf-Agricole, Bologna, Italia.

Hanwen, W., Jim, P., Deirdre, L., De, A. and Min, L.L. (2007) Autotoxicity of wheat (Triticum aestivum L.) as determined by laboratory bioassays. Plant Soil, 296, 85-93.

Harri, L. (2006) Manual de identificacao e controle de plantas daninhas plantio direto e convencional 6 edicao. Instituto plantarum de estudos da flora Ltda.

James, J.H. (2009) Using Cover Crops to Improve Soil and Water Quality. Fact sheet, Ohio State University Extension, http://ohioline.osu.edu.

Kemper, B. (1981) Soil compaction and root growth in Paraná. In: RUSSEL, R.S.; IGHE, K.; MEHTA, Y.R. The soil/root system in relation to Brazilian agriculture. Londrina: Fundação IAPAR :81-101.

Morgan, J.W. (1997) The effect of grassland gap size on establishment, growth and flowering of the endangered Rutidosis leptorrhynchoides (Asteraceae). J. Appl. Ecol., 34, 566-576.

Munshower, F.F. (1994) Practical handbook of disturbed land revegetation. Lewis, Ann Arbor, Michigan, USA. Nelson, J. F. and R. M. Chew. 1977. Factors affecting seed reserves in the Mojave Desert ecosystem, Rock Valley, Nye County, Nevada. American Midland Naturalist, 97, 300-320.

Negri, J.D. (1988) De Práticas culturais para o aumento da produtividade dos citros In:Simpósio De Citricultura, 3., Jaboticabal. Anais... Jaboticabal: FUNEP, : 205-219.

Neves, C.S.V.J., Ives, M.M., Neusa, M.C.S., Cristiane de Conti, M., Andrey, V.B., Sergio, H.O., Roberto, H., Chian, L. and Hernandes, T.K. (2004) Root distribution of rootstocks for 'tahiti' lime. Sci. Agric. (Piracicaba, Braz.), 61 (1), 94-99 .

Neves, C.S.V.J., Dechen, A.R., Feller, C., Abi Saab, O.J.G. and Piedade, S.M.S (1998) Efeito do manejo do solo no sistema radicular de tangerineira 'Poncã' enxertada sobre limoeiro 'Cravo' em Latossolo roxo. Revista Brasileira de Fruticultura, 20,146-253.

Ranells, N.N. and Wagger, M.G. (1997) Winter grass-legume bicultures for efficient nitrogen management in no-till corn. Agriculture, Ecosystems and Environment, 65, $23-32$ 
Sainju, U.M. and Singh, B.P. (1997) Winter cover crops for sustainable agricultural systems: Influence on soil properties, water quality and crop yields. Hort Science, 32, $21-28$

Snedecor, G.W. and Cochran, W.G. (1972) Statistical Methods, $6^{\text {th }}$ ed. lowa State Univ., Amess. lowa.

Turell, F.M. (1965) Comparative nocturnal thermal budgets of large and small citrus trees. Ecology, 46, 25-34.

UNCTAD (2004) http://www.unctad.org/infocomm/anglais/orange/market.htm

USDA (1998) Managing Cover Crops Profitably 3rd. Handbook Series Book 9 Sustainable Agriculture Network. 10300 Baltimore Ave., Bldg. 046 Beltsville, MD 20705 www.sare.org.

Williams, M. and R.R. Weil (2004) Crop Cover Root Channels May Alleviate Soil Compaction Effects on Soybean Crop. Soil Sci. Soc. Am. J., 68, 1403-1409.

Yost, R. and D. Evans (1988) "Green manures and legume covers in the tropics." Hawaii Agricultural Experiment Station. HITAHR College of Tropical Agriculture and Human Resources. Research Series, 055. pp. 16 - 17.

(Received 7/2/2013;

accepted 14/4/2013) 


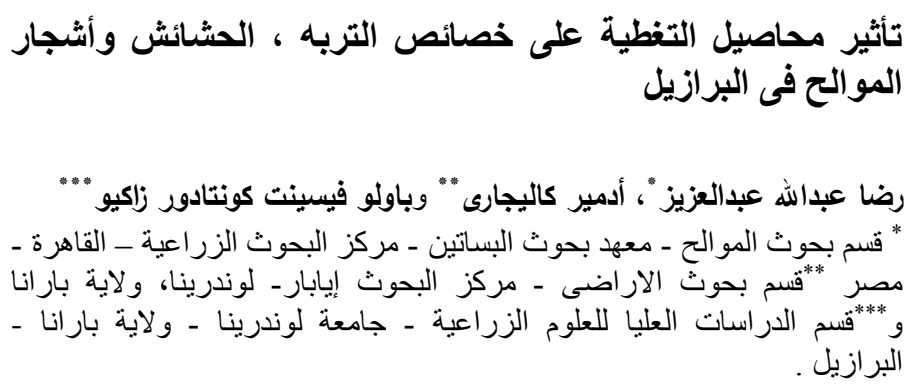

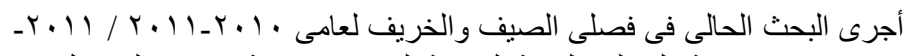

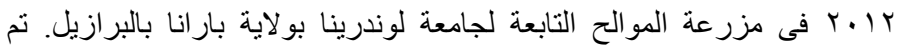

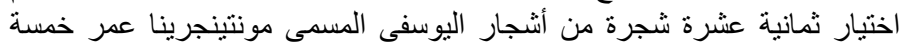

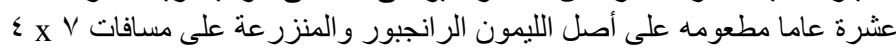

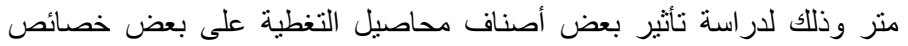

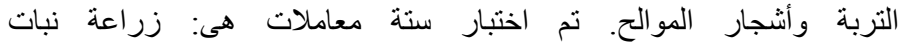

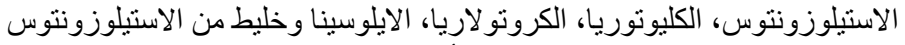

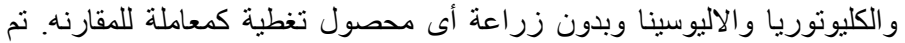

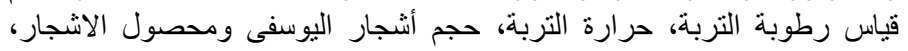

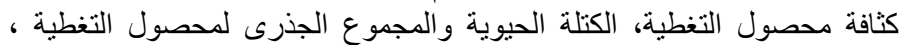

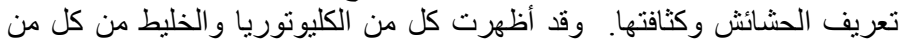
الاستيلوزونتوس و الكليوتوريا والاليو سينا أفضل النيان النتائج.

الكلمات المفتاحية: المو الح ، الحشائش، محاصيل التغطية ، المحصول.
\end{abstract}

